\title{
A SYSTEM FOR PERSONALIZED CLOTHING PRODUCTION AS A MODEL FOR SUPPORTING THE COMPETITIVENESS OF SMES ON THE EXAMPLE OF LODZ PROVINCE
}

\author{
Katarzyna Kędzia ${ }^{1, *}$, Radosław Dziuba² \\ 1 Lodz University of Technology, Faculty of Material Technologies and Textile Design, Lodz, Poland \\ 2 University of Lodz, Faculty of Economics and Sociology, Institute of Economics, Lodz, Poland \\ *Corresponding author. E-mail: kkedzia@yahoo.co.uk
}

\begin{abstract}
:
Poland's accession to the European Union has given many opportunities both in terms of access to the EU economy and European funds. Owing to the set sustainable development goals, the business sphere faces the challenge of their implementation through, among others, activities in the area of social and human capital, and environmental protection. It is important to model solutions that enable sustainable production and consumption. The introduction of innovative product and process technologies may contribute to increasing the competitiveness of SMEs in the Textile and Clothing sector, which in consequence should also contribute to the implementation of objectives of the Regional Smart Specializations for Lodz Province. An example of such solutions is the system for personalized production of clothes presented in the article. The aim of the article is to determine the current situation of the Polish clothing industry in trade with the European Union by analyzing comparative advantages for CN 61 and 62 (related to the clothing industry) and presenting the level of innovation of Lodz Province against the background of Poland as a region specializing in the production of clothing under the adopted Regional Smart Specializations for Lodz Province. It is assumed that the presented system for the personalized production of clothing may affect the competitiveness of this industry and the region.
\end{abstract}

\section{Keywords:}

Clothing \& textile industry, comparative advantages of clothing sector, economic European integration, innovation in clothing, SMEs of clothing industry, personalized production, social manufacturing, sustainable development

\section{Introduction}

Textile and clothing industry (TCl) is a strong element of the global economy with high financial potential. It represents the culture of regions, creates trends and behaviors. As one of the manufacturing industries, in 2015 it accounted for $3 \%$ of global GDP and is expected to grow further [1]. The TCl industry will build its future based on the possibilities of creating highly innovative products [2]. Their production should use new technologies, but also flexible and advanced organizational systems, taking into account the issues of sustainable development and including the needs of a target customer - the customer who is the beneficiary of the $\mathrm{TCl}$ production and his needs are of key importance in creating the industry of the future. Entrepreneurs also face the task of sustainable production and consumption, which should be promoted among consumers. Basing the construction of production systems on this assumption, the customer should be involved already at this stage of product creation. The latest trends show the growing role of social co-creation in various fields of production and further development of the D2C and C2C cooperation model (direct-to-consumer; consumer-to-consumer).
Against a global and European background, Poland has an important contribution in creating the value of the $\mathrm{TCl}$ industry. Thanks to joining the European Union, Poland gained many opportunities for further development and transformation of this industry from labor-intensive to science-intensive. This process began in 2004 and continues unabated, forcing the TCI industry to adapt to European competition. A special role is played here by the Europe 2020 Strategy adopted by EU member states whose aim is to improve the competitiveness of the European economy. The priorities of the strategy include smart and sustainable development, supporting social inclusion through a high level of employment [3]. Against this background, Regional Innovation Strategies have been established. The Lodz Region is an example of an area historically closely related to the analyzed $\mathrm{TCl}$ industry. For the region, smart specializations were determined by analyzing the use of current scientific achievements and economic potential. One of them was the Modern Textile and Fashion Industry (including design) [4]. The presented material illustrates a solution modeled on the basis of one of the niches and the economic area included in point IV/3: "Personalization tools enabling the manufacturing of products with high added value, tailored to the tastes and needs of a customer (both individual and institutional) located anywhere in the value chain." [5] p.6. It is assumed that the 
answer to this issue is the modeling of the original system for personalized clothing production, which is a combination of many innovative technologies in the $\mathrm{TCl}$ industry, as well as information and technological solutions [6].

The aim of the article is to determine the current situation of the Polish clothing industry in trade with the European Union by analyzing comparative advantages for $\mathrm{CN} 61$ and 62 (related to the clothing industry) and presenting the level of innovation of the Lodz Region against the background of Poland as an example of a region specializing in the production of clothing under the adopted Regional Smart Specializations for Lodz Province. On this basis, a system for personalized clothing production will be presented as an innovative solution that could potentially increase the competitiveness of enterprises, with a special focus on SMEs that constitute the quantitative basis of the Polish and EU economy [7][8].

\section{Research Methodology}

\subsection{Comparative advantages evaluation}

The basis for determining the purposefulness of modeling innovative solutions in the presented article is the determination of comparative advantages for the clothing production sector represented by $\mathrm{CN} 61$ and 62 (in accordance with the Combined Nomenclature of Commodity for Foreign Trade - CN 61 Articles of apparel and clothing accessories, knitted or crocheted, CN 62 Articles of apparel and clothing accessories, not knitted or crocheted)[7] and analysis of data contained in the Regional Innovation Scoreboard [9]. As an example of specialization in clothing production, the Lodz Region and its level of innovation will be discussed. The concept of a personalized clothing production system that potentially increases the competitiveness of SMEs in this production sector will be presented further. In the summary, the conclusions and scope of further actions will be defined.

Comparative advantages determine specializations in the foreign trade sector in a given country. They are based on the Balassa theory, where a comparative advantage is defined as the ability of a given economy to produce a specific product more efficiently and is demonstrated by the level of exports of a given good in comparison with the entire exports in relation to the rest of the world [7][10].

"Comparative advantages of the sector result from the relative abundance of some resources and their use in the process of international division of labor." [11] p. 51

In order to determine the comparative advantages, statistical data available in the Eurostat database will be analyzed [12]. This will be a basis for determination of the following indices: Revealed Comparative Advantage (RCA), Import Penetration (IMP) and Relative Trade Advantage (RTA) [7]. The time range of the analysis of comparative advantages includes data from 2007-2017, the start date being related to the beginning of the financial crisis, and the final one with the last full set of available data.

\subsection{Regional Innovation Level}

Innovation is a factor influencing the level of socio-economic development of the country and the strength of the national economy [13], which is why it was decided that the level of innovation in the regions will be discussed on the basis of RIS 2017 [14]. Basically, the report methodology assumes the use of the same indices as the European Innovation Scoreboard (EIS) to assess the state of regional innovation, but some data are not available. The basic components that influence the determination of the level of innovation include Human resources, Attractive research systems, Innovationfriendly environment, Finance and support, Firm investments, Innovators, Linkages, Intellectual assets, Employment impacts and Sales impacts.

\subsection{Personalized production system}

Presentation of the concept of a personalized clothing production system will serve as an example of applying innovative solutions to product individualization and inclusion of a target customer in the process of its manufacturing. Potential benefits resulting from the application of the system, related to the increase of SMEs competitiveness, inclusion of the target customer and issues of sustainable development will be described.

\section{Results and discussion}

\subsection{Results of the analysis of comparative advantages and innovation level in the Lodz Region}

In the analyzed time period, the RTA values have been decreasing since 2007 (Table 1) (Fig.1). They reached the value below unity in 2010; this trend was maintained until the end of the analyzed period (the RTA value below unity indicates that there are no comparative advantages). On this basis, the situation of Polish trade for the $\mathrm{CN} 61$ and 62 sectors is unfavorable, and according to the data for 2017, does not show comparative advantages with respect to trade with the EU. However, it should be emphasized that the RTA values are close to unity, which is a positive trend. The analysis also reveals too high absorption of Polish imports, which negatively affects comparative advantages. It may be concluded that this situation could be improved by increasing the value of Polish exports to European Union countries, i.e. support for SMEs in the production of competitive goods and services of the clothing industry. A solution may be the modeling of the innovative process with high value added based on advanced technologies and educated employees. Only such a solution, as difficult to copy, can build a long-term competitive advantage and ensure a unique character of exported products.

\subsection{Evaluation of the innovation level of the Lodz Region}

To determine the level of innovation in the Lodz Region, the analysis of the Regional Innovation Scoreboard 2017 report was used [9]. The RII index is presented below for all Polish regions according to the Nomenclature of Territorial Units for Statistics 
Table 1. RCA and IMP indices and RTA index calculated on their basis. The author's calculations based on the Eurostat data [12]

\begin{tabular}{|l|l|l|l|}
\hline YEAR & RCA & IMP & RTA \\
\hline 2007 & 0.87 & 0.53 & $\mathbf{1 . 6 4}$ \\
\hline 2008 & 1.02 & 0.79 & $\mathbf{1 . 2 9}$ \\
\hline 2009 & 1.02 & 1.00 & $\mathbf{1 . 0 2}$ \\
\hline 2010 & 1.02 & 1.09 & $\mathbf{0 . 9 4}$ \\
\hline 2011 & 1.02 & 1.08 & $\mathbf{0 . 9 4}$ \\
\hline 2012 & 0.99 & 1.03 & $\mathbf{0 . 9 6}$ \\
\hline 2013 & 0.97 & 0.98 & $\mathbf{0 . 9 9}$ \\
\hline 2014 & 1.00 & 1.12 & $\mathbf{0 . 8 9}$ \\
\hline 2015 & 1.09 & 1.21 & $\mathbf{0 . 9 0}$ \\
\hline 2016 & 1.13 & 1.21 & $\mathbf{0 . 9 3}$ \\
\hline 2017 & 1.09 & 1.23 & $\mathbf{0 . 8 9}$ \\
\hline
\end{tabular}

(NUTS) (Table 2). The analysis qualifies the Lodz Region for the Moderate Innovator Minus group. Innovativeness of the Lodz Region against the background of the EU and Poland as a Moderate Innovator should be strengthened by works in all areas of the analyzed indices. It is advisable to introduce innovative solutions to improve the SMEs' results in the Lodz Region by designing the process and product innovations that are consistent with Smart Specializations determined for the Lodz Region.

\subsection{Concept of a system for personalized clothing production}

It is assumed that the answer to the previously indicated economic area is the concept of a system for personalized clothing production. The idea of the system is to allow a customer to create and produce a single model of clothing that would be fully adapted to the individual needs of the customer, such as full size, aesthetic (construction, color) and functional adjustment. Personalization is the development of the idea of Mass Customization, which assumes only limited adjustment to the customer's needs. In this concept, the production is based on a group of standardized elements

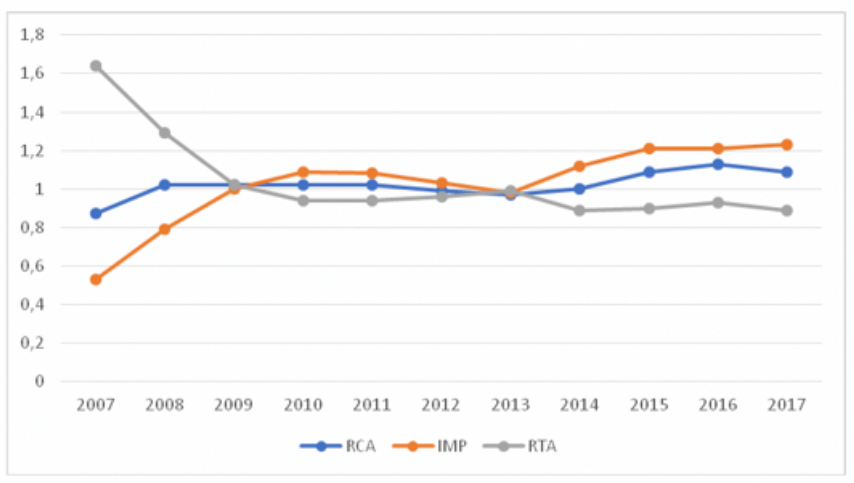

Figure 1. Graphic representation of all indices for CN 61 and 62 in 2007-2017 (author's own study) (without the possibility of an arbitrary choice of personal size or construction) and some elements that can be customized (colors, prints, embroidery). The basic assumption used in building the system of personalized production is that the target customer will be involved in the process of product development and manufacturing based on specific quantitative needs. This trend is currently being undertaken in the context of various types of production. In the clothing production, this issue combines the theory of the value chain, marketing and technological innovation, i.e. the development of the Internet and 3D printing. It appeared in the literature around 2012/13 and is also currently discussed at university centers in China, the United States and Finland [14]. In the literature of 2012, there is Markillie's description [15] p. 4:

"(...) a new industry is emerging. It might be called social manufacturing. (...) much of what is coming will empower small and medium-sized firms and individual entrepreneurs."

The main elements used in building the system include the basic infrastructure necessary to undertake customer-company interaction, a certain business model and preparation of the company to implement the system, as well as an offline service, that is all necessary equipment to enable the system operation (e.g. 3D printer, body scanners) and an online service, i.e. a software that gives the ability to combine all system elements both on the company and customer part. Completion of the process must be the stage of production and delivery of the product to individual customers. Such a system is a response to the trend occurring among consumers, such as increased interest in personalized production (fully adapted in terms of size, aesthetics and functions) and the issue of sustainable consumption and production. In order for existing enterprises not to replicate old schemes and have a chance to simply implement the system for personalized production, the value chain should be re-modeled, this time taking into account social manufacturing, necessary technological innovations and properly educated entrepreneurs and employees. It is important to introduce appropriate innovations adequate to the current development of science and to reduce operations to the necessary minimum. The concept of the system is based on a sequence of actions, according to the following scheme (Fig.2).

The individual process stages, transition through subsequent levels, proposed technologies and equipment used will be described below. The program can be configured with any elements depending on the company's strategy. It is assumed that the simplest version of the program allows for the production of one assortment and the whole process may take place outside the enterprise (outsourcing activity). The system can be introduced in an enterprise of any size, be the basis of business or just an idea of the functioning of one department. Its feature is the ability to model the profile of production and components depending on the specialization and capabilities of the company. For example, the use of textronics will enrich the offer of clothing personalization and give it intelligent functional features, thus clothing with such applications will also become a company profile, and the R\&D partner will have a chance to check the significance and functioning of the developed technologies. An example of modeling the 
Table 2. RII index for the regions of Poland vs. EU-28; the RII index for EU-28 is 100 in 2011. The author's elaboration of results presented in the RIS 2017 report [9]

\begin{tabular}{|c|c|c|c|c|c|c|}
\hline NUTS & NAME & RII2009 & RII2011 & RII2017 & $\begin{array}{c}\text { RII 2017 RELATIVE } \\
\text { TO EU-28 in 2017 }\end{array}$ & INNOVATORS GROUP \\
\hline EU28 & EU28 & 97.3 & 100.0 & 102.6 & 100 & - \\
\hline PL11 & Łódzkie & 46.0 & 47.0 & 51.7 & 50.4 & MODERATE - \\
\hline PL12 & Mazowieckie & 65.3 & 65.4 & 65.3 & 63.6 & MODERATE \\
\hline PL21 & Małopolskie & 56.7 & 54.0 & 58.7 & 57.2 & MODERATE - \\
\hline PL51 & Dolnośląskie & 56.9 & 54.7 & 58.4 & 56.9 & MODERATE - \\
\hline PL63 & Pomorskie & 56.4 & 56.0 & 56.5 & 55.0 & MODERATE - \\
\hline PL32 & Podkarpackie & 49.7 & 50.3 & 53.2 & 51.8 & MODERATE - \\
\hline PL22 & Śląskie & 56.3 & 49.5 & 51.6 & 50.3 & MODERATE - \\
\hline PL41 & Wielkopolskie & 48.4 & 48.2 & 50.6 & 49.3 & MODEST + \\
\hline PL31 & Lubelskie & 40.6 & 42.6 & 48.2 & 47.4 & MODEST + \\
\hline PL42 & Zachodniopomorskie & 46.5 & 47.5 & 47.5 & 46.3 & MODEST + \\
\hline PL61 & Kujawsko-Pomorskie & 45.0 & 41.6 & 46.7 & 45.5 & MODEST \\
\hline PL34 & Podlaskie & 51.3 & 45.4 & 44.9 & 43.7 & MODEST \\
\hline PL52 & Opolskie & 41.1 & 39.1 & 42.2 & 41.1 & MODEST \\
\hline PL43 & Lubuskie & 40.6 & 43.3 & 39.9 & 38.9 & MODEST \\
\hline PL62 & Warmińsko -Mazurskie & 44.5 & 37.2 & 37.8 & 36.8 & MODEST \\
\hline PL33 & Świętokrzyskie & MODEST - \\
\hline
\end{tabular}

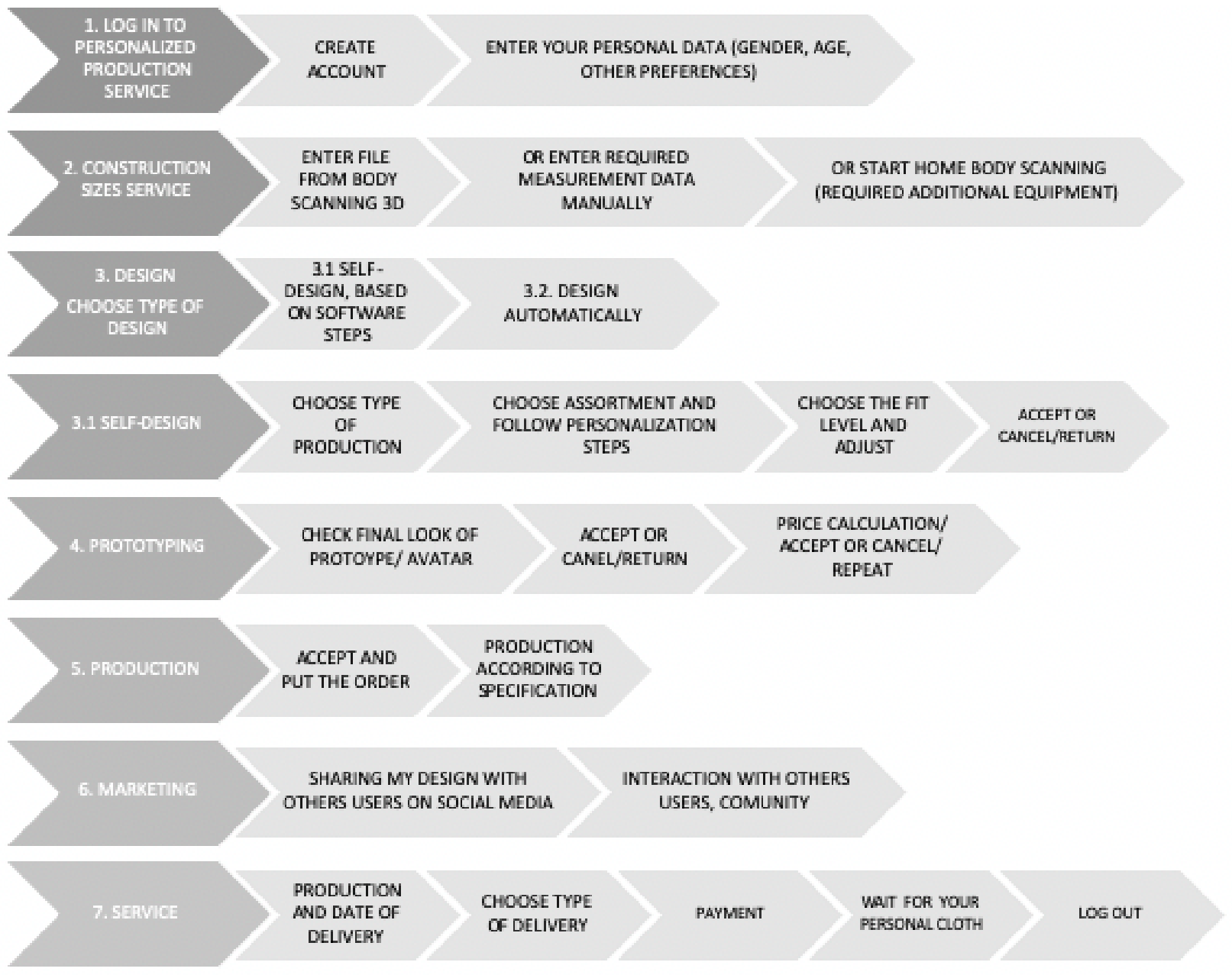

Figure 2. Scheme of the interface from the system user's level. The most important stages of the process. Author's own elaboration 
system depending on the company's specialization can also be the personalization in the field of printing on fabric and further sewing of a specific category of products. It should be emphasized that the prototyping stage occurs throughout

Table 3. Description of the process of personalized clothing production

\begin{abstract}
1. Logging into the system of personalized clothing production (as in Fig. 2)
Result: user account with full data for further analysis.

Requirements: suitable devices for data processing and storage. Introduction of VR technology to create an avatar and virtual fitting

2. Construction - size table (options, one choice).

-enter the file from the performed body scan, assuming to have data from the body scan service performed at the point specializing in this type of services (commercial system of using body scanners possible to be developed outside the designed system);

-enter the necessary dimensions manually, assuming to enter the required and necessary amount of dimensions into the program. For this purpose, the user goes through the subsequent stages showing the method of collecting body dimensions through presentation on the avatar, saving in the form of a table - a data set, with the possibility of editing (an option in which for long-term use and reduction or increase of dimensions, it is possible to change parameters, adjustment); -body scanning assumes the use of a camera installed at home, in this option it is necessary to have additional equipment and access to the program of data processing from the camera (a system to develop, low precision of data collection)

Result: supplementing the user's account with data related to his detailed dimensions, creation of a 3D user avatar with full possibility of rotation and movement simulation (important in the case of material drapeability), application of VR technology.

Requirements: on part of the enterprise, as in the previous stage, devices allowing for data storage and processing. Establishing contact with a company that scans body shape and, if necessary, indication of the scan location to customers. Incorporation of the latest solutions related to body scanning with structural light, development of scanning service for individual users.
\end{abstract}

\title{
3. Designing. The basic choice of design methods.
}

3.1. Original designing based on the path modeled with the personalization program assumes that the user is guided through the system of subsequent stages on which he makes more and more detailed choices defining the preferred appearance of garments;

3.2. Automatic designing assumes the use of the DCGAN (Deep Convolutional Generative Adversarial Networks) intelligent design system [16]; in this model, the user specifies style preferences and assortment, the system itself gives suggestions for acceptance and the next stage is production.

Result: transition to the next stage of the program.

Requirements: devices allowing for data storage and processing, purchase of a separate DCGAN system, the use of artificial intelligence Al, the use of the latest CAD systems.

3.1. Original designing (if the above option of original designing has been chosen), the company must first determine the assortment of products to narrow the program options.

-choice of the production method assumes the initial choice between automatic/traditional manual sewing, knitting, 3D printing and an additional option of laser printing on the material. These options must be pre-determined by the company, for instance, if only 3D printing is assumed, this choice determines further stages of personalization (e.g. 3D printing only for the production of blouses, skirts and dresses due to the capabilities of the company). If the user chooses the option of laser printing on the material, further choices will depend on technological capabilities of the system.

-the choice of the assortment assumes a selection from the group of all items of clothing that can be produced by the given enterprises, program restrictions are modeled by the entrepreneur with regard to production capabilities (e.g. in the earlier selection of knitting, not all assortments may be available). The basic selection from the group includes blouses, dresses, pants, skirts, sweaters, shirts, jackets, coats, shoes and underwear.

A 2D library of a given assortment is displayed, the object closest to the customer's expectations is selected, which can be modified in a further step. After selecting the basic $2 \mathrm{D}$ model, it is presented to the user on the $3 \mathrm{D}$ avatar.

-making modifications in the selected assortment assumes the selection of a cut using a tool for modifying and adding construction lines, changing the length and other parameters related to the cut, changes are visible on the $3 \mathrm{D}$ avatar.

-selection of the assortment details assumes the addition of all elements possible to use, taking into account previously made choices, such as collars, cuffs, types of fasteners, additional cuts, straps, etc. Modifications in the shape of selected details are also assumed. The choice is visible on the 3D avatar. -the choice of material assumes a choice between fabric, knitted fabric, a 3D printing filament (for example, if a knitting system was previously chosen, the choice would be limited only to sweaters or knitted fabrics). The program will force the determination of material for each construction element of clothing (e.g. for a jacket, the program will demand identification of material for each element of the top, wadding, lining or will indicate their lack, if required by the user). If the entrepreneur does not demand a change of the program, the earlier selection of production method and assortment determines the choice of material (e.g. the choice of automatic sewing of the jacket decides about the use of a specific group of fabrics). The choice of material will be possible after extending the option with a library of materials, where 3D models will be presented on a small figure and sample in close-up. The content of libraries of materials is adapted to the entrepreneur's production and storage capabilities. After selecting the material, it is presented on the avatar and on the previously selected basic assortment in the base color (gray).

-determining the degree of product fit assumes the option of selecting the percentage fitting to the figure, depending on the material used and its composition. Simulation, by marking with a color scale, of the degree of tightening the body makes it possible to visually present loose fitting. The effect is visible on the $3 \mathrm{D}$ avatar.

-the choice of color and pattern assumes determination of the color or pattern available for previously made selection (e.g. if the user chose $3 D$ printing, there is a limited possibility to choose a color, or if he chose the traditional dress sewing the possibilities would be broader but still determined by the entrepreneur). The choice of color and pattern applies to each piece of garment construction. The color selection also applies to accessories.

-introducing one's own graphic for printing onto a fragment or entire clothing, through examples from the library or one's own project/picture. The stage assumes introducing the graphic one by one or multiplicating it. Determination of the position, size, possible adjustment of the range of colors. The effect is visible on the 3D avatar.

-selection of accessories in the form of buttons, applications, embroidery, ready-made decorative elements from the library of accessories, it is assumed that one's own graphic for embroidery can be introduced or simple graphics based on the program can be designed. The effect is visible on the 3D avatar.

Result: a full picture of the choices made in the form of a prototype, a 3D avatar.

Requirements: data processing and storage devices, defining the company's production profile to enable/ disable program modules (configuration). Including into the process a possibility of printing accessories on a 3D printer and laser printing as directed by the customer. CAD software for design. 
Table 3 continued. Description of the process of personalized clothing production

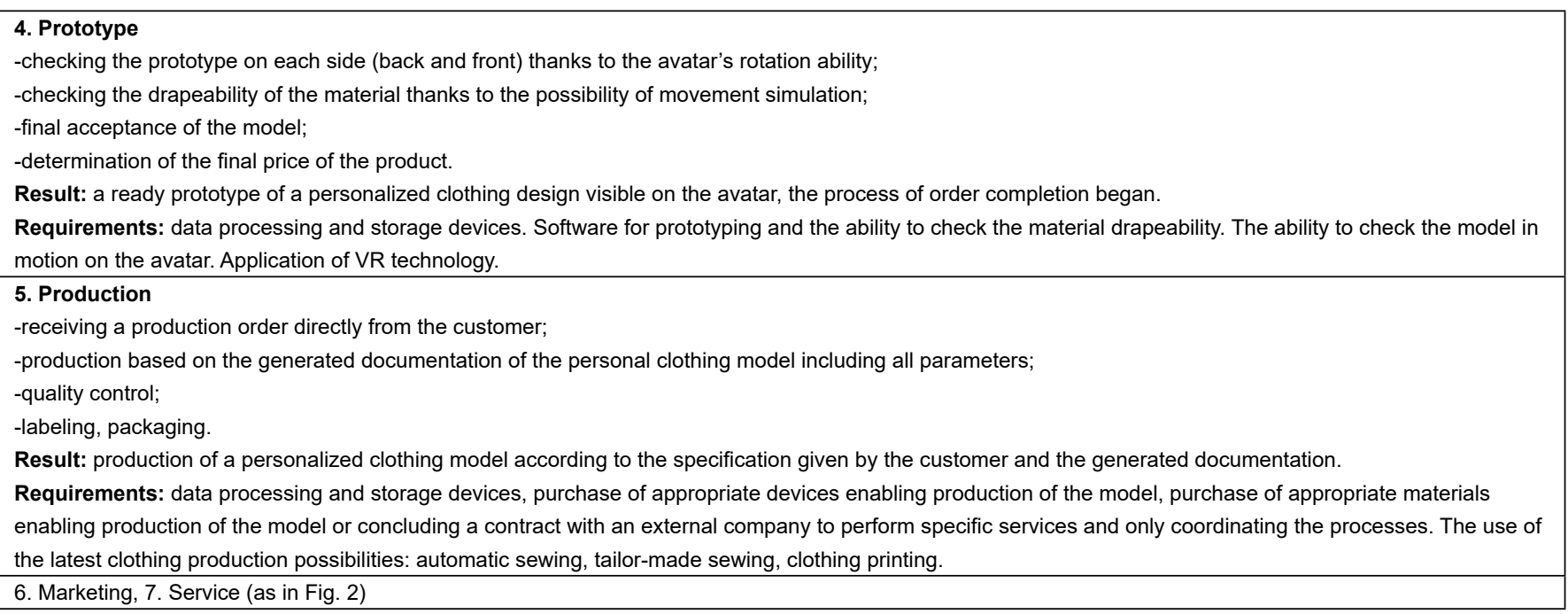

all stages of the process (combines them) and only its final acceptance is a separate phase. One can return to each stage by introducing modifications (Table 3 ).

Basic elements necessary for the system to function:

-user: computer or smartphone, internet network, optional access to the $3 \mathrm{D}$ body scanning point (not necessary), the possibility of electronic payments;

-entrepreneur: purchase of the described software for clothes personalization, appropriate software to efficiently handle the program and database, access to equipment that makes it possible to produce clothes or sign contracts with companies performing specific services (3D body scanning, 3D printing, automatic sewing of clothes, 3D knitting, traditional sewing, making additions and logos, digital printing on various materials), employment or delegating people to operate the system, organizing the payment and delivery system, marketing activities and customer service.

The described process can be modified (expanded or limited) depending on the entrepreneur's needs, however its basic idea of making personalized clothing and involving the customer from the beginning of the process remains unchanged. The scope of introduced and applied technologies depends on the entrepreneur and constitutes the company's specialization.

The advantages of using a social production system that involves the customer in the product development process mentioned in the literature include, among others, direct contact of the consumer with the producer [17]; support of designing; no production minimum, access to innovation; fresh ideas from customers; fast production and delivery time; customer's impact on value added growth; reduction of the area of traditional stores, costs related to employees, energy and logistics [18]; online service availability; reduction of storage stocks by abandoning mass production, a positive impact on the natural environment - reduction of mass production minimizes environmental pollution.
In addition, thanks to the further advancement of personalized production, sectors providing logistics services, IT systems serving as the basis for building the discussed system, CAD programs focused on adaptation to individual users and automation of clothing production will develop.

\section{CONCLUSIONS}

As a result of preliminary studies showing competitive position of Poland vs. the European Union and against this background of the Łódź Region which is an example of a region specializing in the clothing production under the adopted Regional Smart Specializations for Lodz Province, it is observed that Poland was losing its competitive position against EU countries over the period 2007-2017. One of the recommended actions that should improve this situation is to support competitiveness and, hence, the innovativeness of the clothing sector in the Lodz Region. On this basis, it was recommended that the entrepreneurs of the region of Lodz should implement a modeled system for personalized production of clothing, i.e. an innovative ready-made solution that could improve their offer. The system is a flexible tool for introducing innovative technologies anywhere in the value chain. Each of the technologies used can be outsourced, the entrepreneur is not obliged to purchase the device. It is assumed that this may additionally support cooperation between entrepreneurs. Thanks to the cooperation and grouping of enterprises with complementary services, it is possible to more effectively use the potential of various companies with different specializations. Cooperation can reduce the costs of various activities.

The modeled system is a flexible solution in which the entrepreneur decides about the degree of system implementation and applied technologies. Implementation of specific production solutions and identification of a specific assortment group will result in the establishment of a company specialization. Thus, it supports the creativity of entrepreneurs and leads to the emergence of new innovative products as well as business models and workplaces. 
The form of the system functioning in the online version gives the opportunity to open to global markets also microentrepreneurs who want to present their offer among the others available on the clothing production market.

The system provides opportunities for commercialization and popularization of innovative technologies among individual customers. In particular, 3D scanning seems attractive to the modeled system, regardless of the company's production profile. Commercialization of 3D scanning systems will involve individual customers at an early stage of the process.

By applying the system for personalized production, it was assumed to implement issues related to care for the natural environment, especially by reducing the volume of clothing remaining after unsold mass production. Currently, the clothing industry around the world is struggling with the problem of undesirable supplies and surpluses in the production of clothing. This is a serious problem that is undertaken by the largest clothing corporations in the world. The implementation of systems for personalized clothing production will create more desirable and longer-used models. It will also minimize the amount of mass production. There is a tendency of a slow departure from the mass production, i.e. the transition to sustainable production and consumption.

All of the indicated elements can potentially increase the competitiveness of SMEs in the Lodz Region. It is assumed that the commercialization of innovative technologies through a system for personalized garment production can permanently direct the specialization of companies and strengthen the building of know-how difficult to copy, and support cooperation between SMEs and R\&D centers, which is the basis for the success of Regional Smart Specialization for Lodz Province.

\section{ACKNOWLEDGEMENTS}

The concept of a system of personalized clothing production presented in the article was formulated during the preparation of Katarzyna Kędzia's PhD thesis at the Faculty of Material Technologies and Textile Design, Lodz University of Technology.

\section{References}

[1] Hunderkari, N., et al., (2017). Social Innovation Offers Five Golden Opportunities to the Apparel Industry. AT Kearney. (access 06.2018). www.atkearney.com

[2] Euratex. A European Technology Platform for the future of the textiles and clothing, a vision for 2020. (access 11.2018). www.certh.gr/dat/141D2148/file.pdf

[3] European Commission, (2012). EUROPA 2020 Strategia na rzecz inteligentnego $i$ zrównoważonego rozwoju sprzyjającego włączeniu społecznemu. (access 09.15.2018). http://ec.europa.eu/eu2020/pdf/1_PL_ACT part1_v1.pdf

[4] PricewaterhouseCoopers Polska Sp. z o.o., (2015). Polityka Sektorowa dla branży Nowoczesny Przemyst Włókienniczy i Mody (w tym Wzornictwo). (access 02.2018). www.lodzkie.pl
[5] Wykaz Regionalnych Inteligentnych Specjalizacji Regionu Łódzkiego. (access 05.2018) https://rpo.lodzkie.pl/images/ konkurs_2.3.1_cop_28122015/Wykaz_Regionalnych_ Inteligentnych_Specjalizacji.pdf

[6] Rogut. A., (2007). Strategia przekształceń przemysłu włókienniczo-odzieżowego z pracochłonnego w naukochłonny. Instytut Badań SWSPZ w Łodzi. (Lodz).

[7] Dziuba R., Jabłońska M., Sulak K.,Ławińska K., (2018). Textile Sector of the Visegrad Group Countries in Trade with the European Union. Fibres and Textiles in Eastern Europe 6(132).

[8] Muller. P. et al., (2017). Annual Report on European SMEs 2016/2017 Focus on self-employment. (access 10.2018). www.ec.europa.eu

[9] Regional Innovation Scoreboard 2017, (access 09.26.2018). www.ec.europa.eu,

[10] Szczepaniak. I., (2018). Przewagi komparatywne w handlu zagranicznym Polski na przykładzie produktów rolno-spożywczych i pozostałych. Zeszyty Naukowe Szkoły Głównej Gospodarstwa Wiejskiego w Warszawie, Problemy rolnictwa światowego tom 18(33) zesz.1.

[11] Posłuszny. K., (2011). Konkurencyjność międzynarodowa jako miara skuteczności restrukturyzacji przemysłu. K. Posłuszny, Ekonomia Menedżerska nr 9.

[12] Eurostat. https://ec.europa.eu/eurostat/data/database (access 01.2019)

[13] Jabłońska. M., (2013). Finansowanie pomysłów innowacyjnych małych $i$ średnich przedsiębiorstw na przykładzie Competitiveness and Innovation Framework Programme (CIP). Studia Ekonomiczne $n r$ 174, Wydawnictwo Uniwersytetu Ekonomicznego w Katowicach. p. 336.

[14] Xiuqin. S. et al., (2013). Social Manufacturing Cloud Service Platform for the Mass Customization in Apparel Industry. IEEE. International Conference on Service Operations and Logistics, and Informatics China. Article number 6611413, pp. 220-224. (access 09.2018). From Scopus.

[15] Markillie. P., (2012). A third industrial revolution: Collaboration manufacturing. The Economist, April 21. (access 09.2018). http://web.mit.edu/pie/news/Economist. $p d f$

[16] Kato. N. et al., (2018). DeepWear: A Case Study of Collaborative Design between Human and Artificial Intelligence. In Proceedings of the Twelfth International Conference on Tangible, Embedded, and Embodied Interaction (TEI '18), ACM, New York, NY, USA. pp. 529536. (access 10.2018). From Scopus

[17] Hamalainen. M., Karjalainen. J., (2017). Social Manufacturing: When the maker movement meets interfirm production networks, Business Horizon 60, pp.795-805. (access 09.2018). From ScienceDirect.

[18] Mohajeri. B. et al., (2014). The Impact of Social manufacturing on the Value Chain Model in the Apparel Industry, Proceedings of 2014 IEEE, China. Article number 6960754, pp. 378-381. (access 12.2018). From IEEE Explore. 